WellBeing International

WBI Studies Repository

$1-1989$

\title{
Acceptance of Simulated Oral Rabies Vaccine Baits by Urban Raccoons
}

\author{
John Hadidian \\ National Park Service \\ Suzanne R. Jenkins \\ Virginia Department of Health \\ David H. Johnston \\ Ontario Ministry of Natural Resources \\ Peter J. Savarie \\ Denver Wildlife Research Center \\ Victor F. Nettles \\ University of Georgia
}

See next page for additional authors

Follow this and additional works at: https://www.wellbeingintlstudiesrepository.org/acwp_vsm

Part of the Animal Studies Commons, Other Animal Sciences Commons, and the Veterinary Microbiology and Immunobiology Commons

\section{Recommended Citation}

Hadidian, J., Jenkins, S. R., Johnston, D. H., Savarie, P. J., Nettles, V. F., Manski, D., \& Baer, G. M. (1989).

Acceptance of simulated oral rabies vaccine baits by urban raccoons. Journal of Wildlife Diseases, 25(1), $1-9$.

This material is brought to you for free and open access by WellBeing International. It has been accepted for inclusion by an authorized administrator of the WBI Studies Repository. For more information, please contact wbisr-info@wellbeingintl.org.

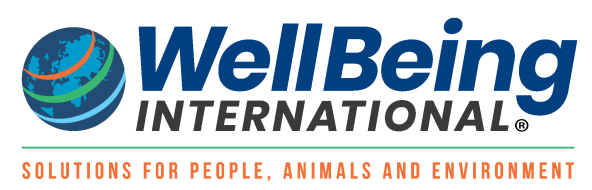




\section{Authors}

John Hadidian, Suzanne R. Jenkins, David H. Johnston, Peter J. Savarie, Victor F. Nettles, David M. Manski, and George M. Baer 


\title{
ACCEPTANCE OF SIMULATED ORAL RABIES VACCINE BAITS BY URBAN RACCOONS
}

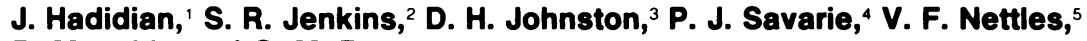 \\ D. Manski, ${ }^{6}$ and G. M. Baer \\ ' National Park Service, Center for Urban Ecology, 1100 Ohio Drive SW, Washington, D.C. 20242, USA \\ ${ }^{2}$ Virginia Department of Health, Office of Epidemiology, Richmond, Virginia 23219, USA \\ ${ }^{3}$ Ontario Ministry of Natural Resources, Wildlife Research Section, Maple, Ontario, Canada LOJ 1EO \\ ${ }^{4}$ USDA/APHIS/ADC, Denver Wildlife Research Center, Building 16, Federal Center, Denver, Colorado 80225, USA \\ ${ }^{5}$ Southeastern Cooperative Wildlife Disease Study, College of Veterinary Medicine, University of Georgia, \\ Athens, Georgia 30602, USA \\ ${ }^{6}$ Aniakchak National Monument and Preserve, P.O. Box 7, King Salmon, Alaska 99613, USA \\ ' Rabies Laboratory, Division of Viral Diseases, Centers for Disease Control, Box 363, \\ Lawrenceville, Georgia 30245, USA
}

ABSTRACT: In summer 1986, a study was conducted to evaluate raccoon (Procyon lotor) acceptance of oral baits that could be used for rabies vaccination. One thousand wax-coated sponge bait cubes were filled with $5 \mathrm{mg}$ of a seromarker (iophenoxic acid), placed in polyethylene bags, and hand-distributed in an 80 ha area within an urban National Park in Washington, D.C. (USA). After $3 \mathrm{wk}$, target and nontarget animals were trapped and blood samples collected to evaluate bait uptake. Thirty-three of $52(63 \%)$ raccoons had elevated blood iodine levels indicating they had eaten at least one bait, $13(25 \%)$ were negative, and six $(12 \%)$ had marginal values. These results indicate that sponge baits hand-placed at a density of 12.4 /ha can reach a significant proportion of an urban raccoon population. Implications for oral rabies vaccination of raccoons are discussed.

Key words: Oral baiting, rabies, raccoon, seromarker, urban population, Procyon lotor, field study.

\section{INTRODUCTION}

The objective of this study was to test an oral bait delivery strategy in a population of urban raccoons (Procyon lotor). As used herein, oral baiting implies the consumption by a target species of a chemical or biological agent that, without concealment or inclusion in a preferred food, would otherwise be unlikely to be taken. While the delivery of poisons has undoubtedly been the oldest and most common application, oral baits also have been used in immunization programs, to mark animals for population studies, study various physiological processes and deliver chemosterilants in population control efforts. One use of both laboratory and field baits has been the delivery of oral rabies vaccines (Baer et al., 1971; Winkler and Baer, 1976; Steck et al., 1982; Schneider et al., 1983; Johnston et al., 1989).

A raccoon rabies epizootic in the midAtlantic region of the United States has recently focused attention on the need for rabies control in that species (Jenkins and
Winkler, 1987). Since raccoons may be found in a variety of habitats (Kaufmann, 1983) and frequently live in close contact with humans (Hoffmann and Gottschang, 1977), rabies control in this species is likely to pose particular problems. Raccoons in urban and suburban areas are often found in high numbers (Schinner and Cauley, 1974; Rosatte, 1985; Slate, 1985), den in occupied residences, and rely on human resources for food sources such as refuse (Manski and Hadidian, 1987), creating a high potential for human-raccoon contacts and special concerns for rabies control officials.

The impact of the mid-Atlantic raccoon rabies epizootic has been felt through a greater burden on animal control and public safety agencies, the need to increase restrictions on public contacts with wild carnivores, and a need for immunizing domestic pets and livestock. With the evident desire to develop a strategy to control raccoon rabies, we conducted this study to test oral baiting as a technique for future urban raccoon immunization.

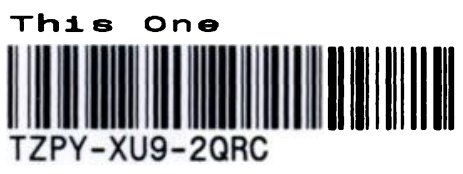




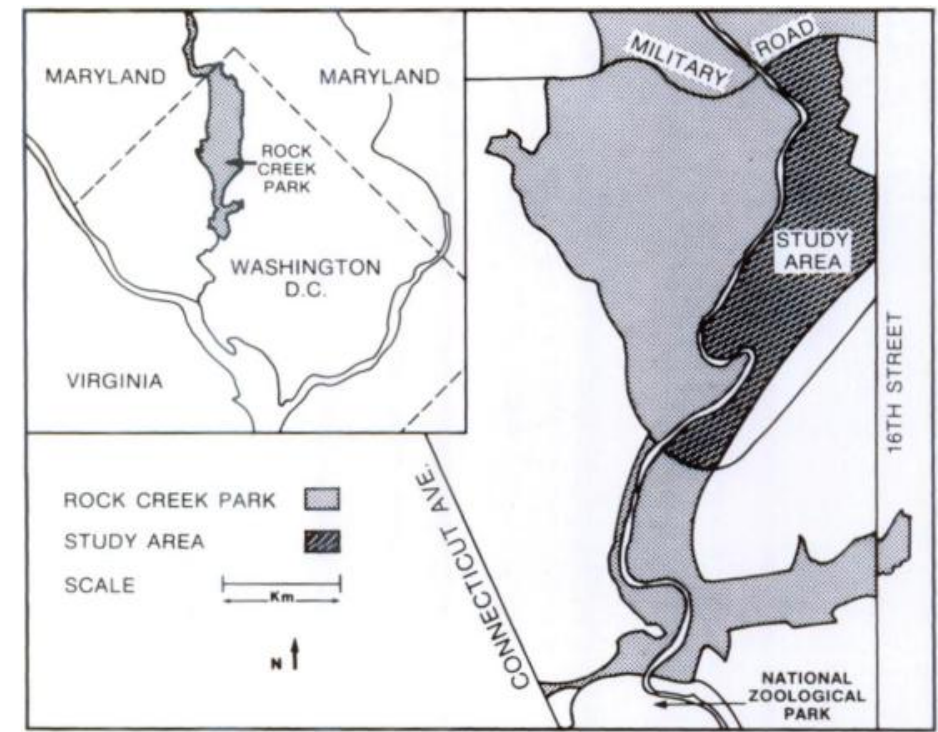

Figure 1. Rock Creek Park, Washington, D.C. (USA) and the study area.

\section{MATERIALS AND METHODS}

\section{Study area}

The study was conducted in Rock Creek Park (ROCR), a 720 ha National Park located in Washington, D.C. $\left(38^{\circ} 57^{\prime} \mathrm{N}, 7^{\circ} 02^{\prime} \mathrm{W}\right)$. An 80 ha test site was chosen in the spring of 1986 (Fig. 1). Approximately $70 \%$ of this area consisted of mature deciduous hardwood forest. The remaining $30 \%$ included an outdoor amphitheater, recreational facilities, picnic areas and several large sports fields. To the east, the test area shared approximately $2.0 \mathrm{~km}$ of border with residential neighborhoods and a $0.7 \mathrm{~km}$ border with recreational areas and sports fields. A public golf course abutted the northern boundary, while the western boundary was defined by the Rock Creek stream drainage itself and the park road paralleling it, Beach Drive. The southern border consisted of a road separating the test area from another wooded section of the park.

Among the larger mammals found in ROCR are raccoons, Virginia opossums (Didelphis virginianus), and foxes, both red (Vulpes vulpes) and gray (Urocyon cinereoargenteus). Domestic cats, both owned and feral, are common, as are owned domestic dogs. Feral dogs are found infrequently. Skunks (Mephitis mephitis), woodchucks (Marmota monax) or rabbits (Sylvilagus spp.) do not live in the park. Research on the raccoon population in ROCR has been ongoing since 1983, and sections of the park, including the 1986 baiting area, have been live trapped in the past, with raccoons examined, individually marked and returned to the park.

\section{Bait preparation}

The bait package included three components: the individual bait cubes, a mackerel slurry used as an attractant, and the polyethylene bag that served as the carrier for both of these. The $3 \times$ $3 \times 3.5 \mathrm{~cm}$ commercially prepared polyurethane foam cubes (Connaught Laboratories Limited, Willowdale, Ontario, Canada M4R 3T4) were machine-cut, and coated with a waxtallow mixture impregnated with $150 \mathrm{mg}$ of tetracycline $\mathrm{HCl}$ as a biomarker (Lawson et al., 1987). Although baits were provided with a tetracycline biomarker, it is National Park Service policy to minimize invasive or manipulative research on wildlife populations within National Park boundaries whenever possible. Since tetracycline analysis would minimally involve the removal of teeth we sought an alternative to this as a biological marker. Therefore, each bait was also injected with $10 \mathrm{ml}$ of a solution of iophenoxic ( $\alpha$-ethyl-3-hydroxy-2,4,6-triiodobenzenepropanoic) acid (IA) as a seromarker (Aldrich Chemical Company, Milwaukee, Wisconsin 53233, USA). This solution was prepared by dissolving $1 \mathrm{~g}$ of IA in $200 \mathrm{ml}$ of commercial corn oil, heated to $90 \mathrm{C}$ for $4 \mathrm{~min}$. This was added to $1,600 \mathrm{ml}$ of distilled water and $200 \mathrm{ml}$ of whole egg, and the mixture was emulsified in a blender for 2 min. After injection, each bait was sealed with a drop of paraffin. Each bait was packaged in a numbered, clear, polyethylene bag $(17 \times 24 \times 0.025 \mathrm{~cm})$ which was stamped with a message identifying it as an experimental bait package.

Between 10 and $20 \mathrm{ml}$ of the mackerel-water 
slurry was placed into each bag. Before baiting, trials were held in another section of the park to evaluate possible attractants. Presentation of baits in two different locations indicated no preferences for any of six preparations (canned mackerel, grape jelly, cod liver oil, feta cheese, fresh banana and commercial beef gravy). Mackerel was chosen because it was easily available and had been effective as a bait in previous raccoon trapping. The baits were kept in a freezer for $\mathbf{4 8} \mathrm{hr}$ before field distribution.

\section{Bait distribution}

Baits were distributed at a density of 12.4 / ha between 8.00 A.M. and 3:00 P.M. on 15 and 16 June 1986. A nine-person team placed baits by hand at $15 \mathrm{~m}$ intervals along 43 transects, using compass bearings for orientation. Nine hundred eighty baits were placed in the field on 16 June, and 20 baits were placed inside a fenced area surrounding an amphitheater on 17 June 1986. A colored plastic streamer was tied to vegetation at every third drop site to allow later relocation of the sites, except on a few lines where a streamer was left at each site. The daily temperature during the period when baits were in the field ranged between a mean high of 30.4 $\mathrm{C}$ to a mean low of $19.2 \mathrm{C}$, with extremes of 36.1 and 15.0 C. Humidity varied from a daily mean high of $81.2 \%$ to a low of $35.6 \%$, with extremes of $100 \%$ and $22 \%$. Rainfall averaged $0.12 \mathrm{~cm} /$ day, with a high of $0.94 \mathrm{~cm}$ falling on 2 July 1986.

\section{Trapping and postbaiting surveys}

Marked locations along randomly chosen transects were checked eight of the first 11 days following distribution to determine whether baits had been moved or taken by wildlife. The locations and immediate surrounding areas were examined for intact baits, partly eaten baits, remains of chewed plastic bags or bait coating where baits had been more completely consumed. Although disturbed baits as described above indicated animal contact, there was no way of identifying what species was involved in every case. New transects were followed each day the baits were checked.

To capture animals for biomarker analysis livetraps (Tomahawk \#207, Tomahawk Live Trap Company, Tomahawk, Wisconsin 54487, USA) were placed at 15 locations within the study area beginning 21 days after the bait drop (6 July 1986). Two livetraps were placed at each site to allow multiple captures where raccoons might be travelling together. Trapsites were chosen so that the area was uniformly covered, and located where signs of raccoons appeared or travel routes were suggested. The traps were set in the late afternoon or early evening and baited with canned mackerel. Traps were checked at dawn, and raccoons, opossums and cats to be examined were transported to a central, indoor location. Traps were set for a total of 10 days in July and for 5 days in October, using the same trapsites.

Raccoons and cats were anesthetized using ketamine hydrochloride (Ketaset, Bristol Laboratories, Bristol-Myers Company, Syracuse, New York 13221, USA) at dosages of $10 \mathrm{mg} / \mathrm{kg}$ (Bigler and Hoff, 1974). All unmarked raccoons were given individual chest tattoos and eartagged. Between 5 and $10 \mathrm{ml}$ of blood was collected from raccoons and cats by jugular venipuncture. The small number of opossums trapped, coupled with difficulties in blood collection from them, prevented an adequate sampling of this species. Serum was removed after the blood clotted, then frozen. All animals were released at original trapsite locations late in the afternoon of the same day they were trapped, after their recovery from anesthesia.

Three age classes were recognized for raccoons: adult, subadult, and young-of-yr. Males were classified as adult if their baculum measured $90 \mathrm{~mm}$ or more and was fully extrudable (Sanderson, 1950, 1961). Females were classified as adult (parous) if teat height measured at least $6 \mathrm{~mm}$ (Stuewer, 1943). Young-of-yr were identified in July by the presence of deciduous dentition and aged by following the tooth eruption sequences of Montgomery (1964). After permanent dentition had developed, young-of-yr were distinguished by a series of criteria, including general tooth wear, weight and canine length (Stuewer, 1943). The subadult class for both sexes included animals of adult size and appearance that apparently had not yet achieved full sexual maturity. Most of these animals were probably 14- to 16-mo-old when examined.

\section{Blood iodine level analysis}

Analysis of serum samples was conducted in the U.S. Department of Agriculture's Animal and Plant Health Inspection Service's (APHIS) Research Center (Denver, Colorado 80225, USA). The analysis of total iodine content in serum samples followed methods similar to those described by Knowlton et al. (1988), with the following modifications: After addition of $1 \mathrm{ml}$ of digestion reagent, each tube was placed in a $195 \mathrm{C} \pm 5 \mathrm{C}$ preheated heating block for $6 \mathrm{~min}$. After cooling to room temperature, $1 \mathrm{ml}$ of ceric reagent was added to each tube, and tubes were placed in a rack in a $30 \mathrm{C}$ water bath for 10 min to equilibrate. At timed $15 \mathrm{sec}$ intervals beginning with the first tube, each tube was 
TABLE 1. Age and sex of raccoons trapped in July and October 1986, and control animals trapped in November 1985 and March and April 1986.

\begin{tabular}{lrrr}
\hline & Male & Female & Total \\
\hline July & & & \\
$\quad$ Adult & 11 & 12 & 23 \\
Subadult & 6 & 7 & 13 \\
Young-of-yr & 11 & 6 & 17 \\
$\quad$ Total & 28 & 25 & 53 \\
October & & & \\
Adult & 3 & 1 & 4 \\
Subadult & 0 & 2 & 2 \\
Young-of-yr & 5 & 4 & 9 \\
$\quad$ Total & 8 & 7 & 15 \\
Controls & & & \\
Adult & 4 & 1 & 5 \\
Subadult & 1 & 1 & 2 \\
Young-of-yr & 5 & 6 & 11 \\
Total & 10 & 8 & 18 \\
\hline
\end{tabular}

- Two animals trapped in July and recaptured during the same trapping period are excluded.

b Two adult males used as controls were sampled twice, in November 1985 and March 1986

removed and $1 \mathrm{ml}$ of Aresenious reagent was added. Tubes were returned to the water bath for exactly $9 \mathrm{~min}$, and at $15 \mathrm{sec}$ intervals the absorbance was measured at $420 \mathrm{~nm}$ in a spectrophotometer. The reagents were prepared according to information (Method File N-56) supplied by Technicon Instruments Corporation (Tarrytown, New York 10591, USA).

Iodine levels were measured in $\mu \mathrm{g} / 100 \mathrm{ml}$. The maximum dilution tested was either 200 $\mu \mathrm{g} / 100 \mathrm{ml}$ or $220 \mu \mathrm{g} / 100 \mathrm{ml}$, depending upon which of two runs the samples were examined. Animals with serum iodine levels of $\geq 20 \mu \mathrm{g}$ / $100 \mathrm{ml}$ were considered to have eaten at least one bait. Animals with blood iodine levels of $\leq 14 \mu \mathrm{g} / 100 \mathrm{ml}$ were considered unmarked. At levels between these two groups (15 to $19 \mu \mathrm{g} /$ $100 \mathrm{ml}$ ) we could not be certain whether animals had consumed bait or not, so those falling within this range were included in a separate group. Serum samples collected from 20 ROCR animals between November 1985 and April 1986 , before the baiting project began, were used as controls to determine background levels of blood iodine $(\bar{x}=5.5, \mathrm{SD}=2.7)$.

Mean blood iodine levels between groups were compared by $t$-tests after sample variances had been tested for equality (Rosner, 1986). Comparison of raccoon captures by trapsite was made using Chi-square analysis. For all tests the level of $\alpha$ was set at 0.01 .

\section{RESULTS}

\section{Population characteristics}

Ninety-five animals were trapped in the two postbaiting sample periods: 68 raccoons, 14 domestic cats, 12 opossums, and one eastern box turtle (Terrapene caroli$n a)$. Raccoons were trapped at all but one location, and there was no significant difference between the number captured at trapping sites $(P>0.30)$. On the basis of 450 trap-nights, and adjusting for recaptures, the capture of other species and sprung traps that resulted in no captures (Lewis and Clark, 1973), trapping success for raccoons was $20 \%$ in July and $12 \%$ in October. Table 1 gives the age-sex categories of raccoons trapped in July and October, as well as those used as controls for baseline iodine blood levels. Eleven raccoons trapped in July (eight females and three males) had been previously trapped, six as early as 1983 . Of the eight for which records were available, only one adult female had been trapped more than $0.25 \mathrm{~km}$ from the test area. She was caught at a site $0.75 \mathrm{~km}$ from the nearest border of the 1986 baiting area in February 1985. Only two animals caught in July were retrapped in October.

Ten of 12 adult females trapped in July were lactating or had recently weaned young. Of 17 young-of-yr trapped in July, 10 were estimated to be between 75- and 78-days-old, while seven were estimated to be $\geq 81$-days-old. The nine young trapped in October all had full permanent dentition, and were at least 4-mo-old.

\section{Bait acceptance: distribution line surveys}

Twenty-seven of the 43 bait distribution lines were surveyed following the drop: 429 marked bait locations were checked (Fig. 2). Bait disappearance was high even on the first day, with more than $80 \%$ of the baits eaten or missing from three lines surveyed. By the end of $1 \mathrm{wk}$ the cumulative total of baits eaten or missing rose to $97 \%$ or greater on all lines checked.

Ants (Formicidae) and carrion beetles 


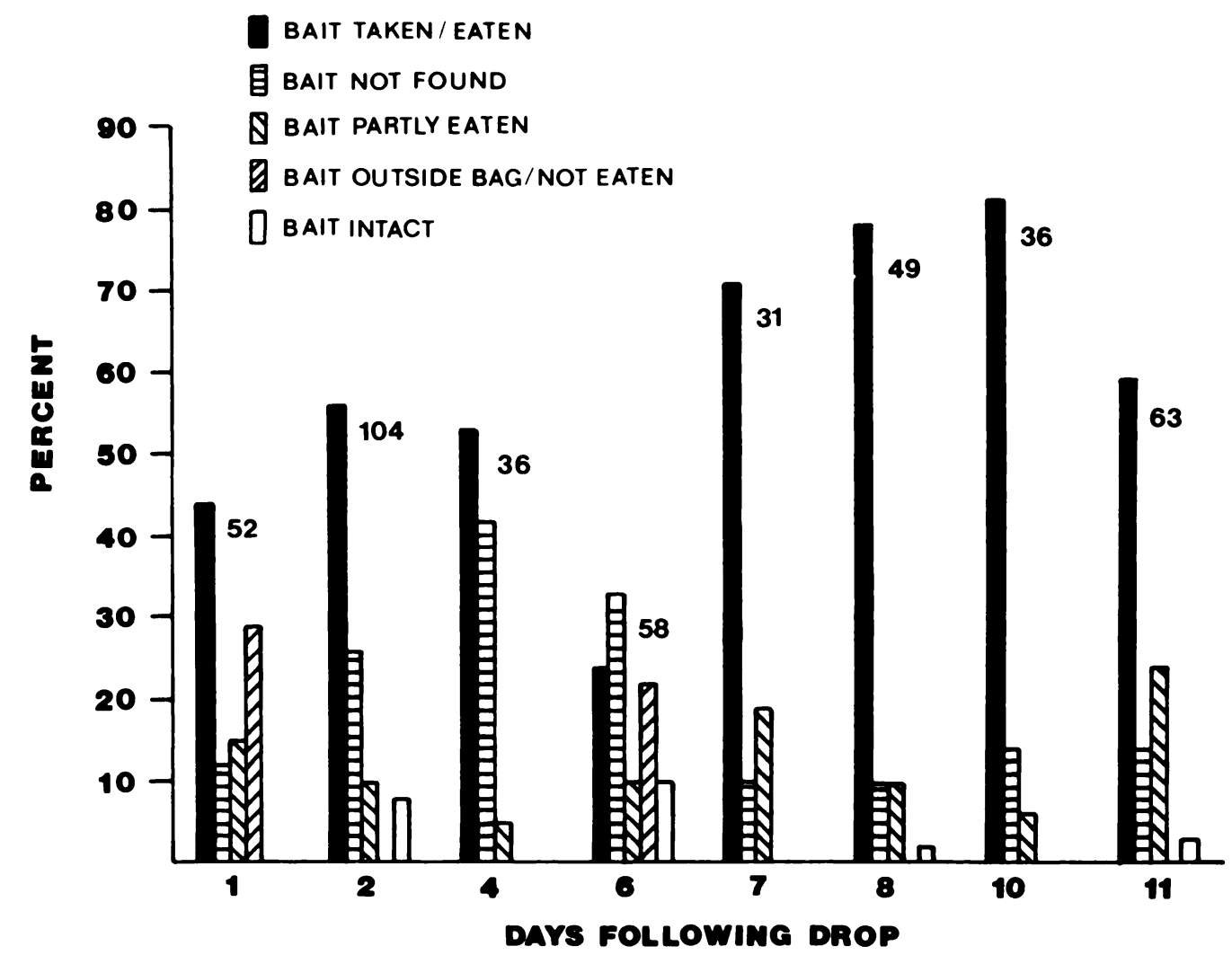

Figure 2. Results of bait line surveys along 27 bait distribution lines, over a period of 11 days following bait placement in the field. Numbers next to figures are the total number of known bait locations examined on each day of the survey.

(Silphidae) were active in many bait bags after 1 or 2 days, but fly activity was very low. Fox (probably red fox) scats, next to or on bait bags, were observed at five of the 429 locations checked. Four of these had wax or sponge fragment inclusions, suggesting that foxes were returning to bait lines or following new bait lines on successive nights.

Thirty-seven days after placement in the field, a final search for uneaten baits and remaining bags was conducted by a team of 10 volunteers. One hundred thirty bags were recovered, of which only five contained intact baits.

\section{Bait acceptance: blood iodine levels}

Blood samples were obtained from 52 of the 53 raccoons caught in July. Thirtythree of the raccoons trapped in July $(63 \%)$
TABLE 2. Iodine levels of raccoons trapped in Rock Creek Park, July 1986, and controls sampled in November 1985 and March and April 1986.

\begin{tabular}{|c|c|c|c|c|}
\hline Status & $n$ & $\begin{array}{c}\text { Mean } \\
(\mu \mathrm{g} \mathrm{I} / \\
100 \mathrm{ml})\end{array}$ & $\begin{array}{l}\text { Stand- } \\
\text { ard } \\
\text { devi- } \\
\text { ation }\end{array}$ & Range \\
\hline Marked & 33 & 143.3 & 73.8 & $20.0->220.0^{\circ}$ \\
\hline \multicolumn{5}{|l|}{ Adult } \\
\hline Male & 5 & 149.8 & 92.5 & $31.0->220.0$ \\
\hline Female & 8 & 131.3 & 86.0 & $20.0->220.0$ \\
\hline \multicolumn{5}{|l|}{ Subadult } \\
\hline Male & 2 & 220.0 & $-b$ & - \\
\hline Female & 7 & 168.4 & 83.0 & $79.0->220.0$ \\
\hline \multicolumn{5}{|c|}{ Young-of-yr } \\
\hline Male & 7 & 91.6 & 36.1 & $27.0-140.0$ \\
\hline Female & 4 & 120.5 & 60.6 & $80.0-210.0$ \\
\hline Unmarked & 13 & 7.3 & 3.8 & $1.6-11.0$ \\
\hline Uncertain & 6 & 15.9 & 1.7 & $15.2-19.2$ \\
\hline Control & 20 & 5.5 & 2.7 & $1.9-9.4$ \\
\hline
\end{tabular}

- Values $>220 \mu \mathrm{g} \mathrm{I} / 100 \mathrm{ml}$ were not determined.

${ }^{b}$ Not tested. 


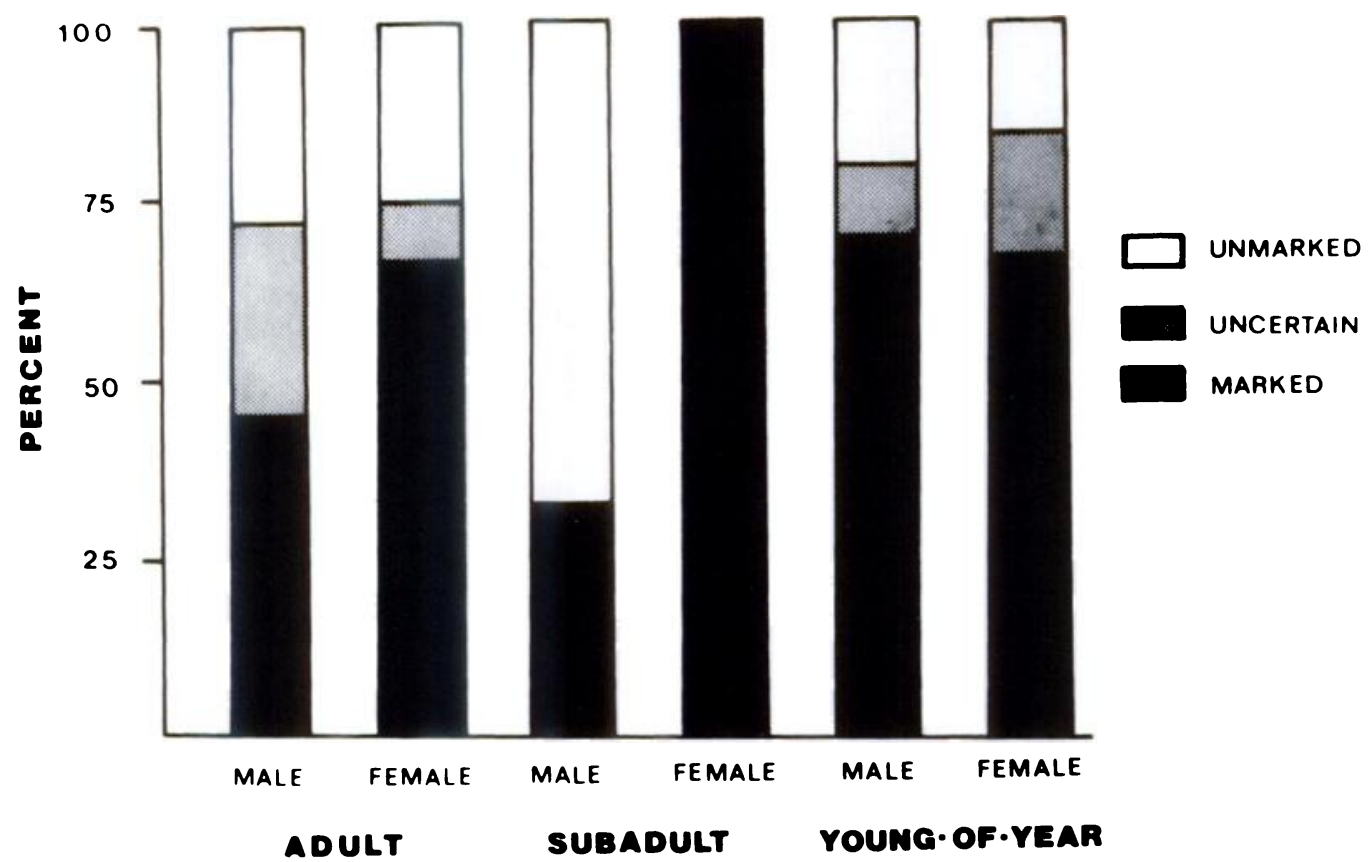

FIGURE 3. Age-sex class and bait acceptance status for 52 raccoons sampled in July 1986. Animals are classified as marked, unmarked or uncertain according to criteria given under Blood iodine analysis in the text.

had been marked after eating $\geq$ one bait, while $13(25 \%)$ were unmarked; six (12\%) were in the intermediate range (Table 2). Among animals grouped by age-sex class, bait acceptance was $<50 \%$ in both the adult and juvenile males (Fig. 3). Acceptance was highest in the juvenile females, where all seven animals examined were marked.

The difference in mean blood iodine level between marked and unmarked animals in July (Table 2) was significant $(P<0.01)$. No significant difference was found between (1) unmarked animals in July and the 20 controls taken before the test $(P<0.01),(2)$ unmarked and controls $(P<0.01)$ in October or $(3)$ unmarked animals in July or October $(P<0.01)$. Although we excluded six animals in July from either the marked or unmarked groups, it should be noted that their mean blood iodine levels were significantly higher than either unmarked $(P<0.01)$ in July, unmarked $(P<0.01)$ in October, or control animals $(P<0.01)$.

Two or more raccoons were caught to- gether at a trapsite on 11 occasions in July. In four of these instances an adult female with $\geq$ one young was trapped, and in another four $\geq$ two young were caught together. In three of the four adult-young groups, marked animals with highly comparable blood iodine levels were caught, while in the fourth an adult female was marked $(20 \mu \mathrm{g} / 100 \mathrm{ml})$ and the single young with her was in the intermediate group $(16 \mu \mathrm{g} / 100 \mathrm{ml})$. In two of the cases where only young were caught, the animals were comparably marked. In a third case one individual was in the intermediate group $(16 \mu \mathrm{g} / 100 \mathrm{ml})$, while its presumed sibling was unmarked $(13 \mu \mathrm{g} / 100$ $\mathrm{ml}$ ). In only one of eight cases where presumed family members were trapped together was marked disparity in blood iodine levels found: a young-of-yr female was clearly marked $(80 \mu \mathrm{g} / 100 \mathrm{ml})$ but her presumed male sibling was not $(10 \mu \mathrm{g} /$ $100 \mathrm{ml}$ ).

Only two of 14 animals trapped in October were considered marked, both hav- 
ing been trapped previously in July. One, a subadult female, had a blood iodine level $>200 \mu \mathrm{g} / 100 \mathrm{ml}$ both in July and October, when she was recaptured 105 days later. The second, a young male, had a level of $109 \mu \mathrm{g} \mathrm{I} / 100 \mathrm{ml}$ on $18 \mathrm{July}$ and 50 on 20 October. Eleven animals (one adult female, three adult males, two female young and five male young) were unmarked at the time of capture. One animal trapped in October was in the intermediate range $(16 \mu \mathrm{g} \mathrm{I} / 100 \mathrm{ml})$. In December 1986, an adult female was recaptured $0.2 \mathrm{~km}$ from the trapsite where she had been caught 163 days earlier in July; her blood iodine level exceeded $200 \mu \mathrm{g} / 100 \mathrm{ml}$ on both occasions.

Although no baseline blood iodine levels were established for feral cats, four animals (two adult males and two adult females) sampled in July had levels that were indicative of marked status in raccoons. One male, with a blood iodine level in excess of $220 \mu \mathrm{g} / 100 \mathrm{ml}$, was retrapped 104 days after his initial capture, at which time his blood iodine level was $195 \mu \mathrm{g} /$ $100 \mathrm{ml}$. The other adult male $(24 \mu \mathrm{g} / 100$ $\mathrm{ml}$ ) and two adult females (29 and $48 \mu \mathrm{g} /$ $100 \mathrm{ml}$ ) had blood iodine levels that were close to the lower limits established for marked raccoons.

\section{DISCUSSION}

This study demonstrates a high level of oral bait acceptance in an urban raccoon population. During the first $3 \mathrm{wk}$ following bait distribution, $63 \%$ of the raccoons examined had ingested one or more baits. Bait disappearance was high from the first day following distribution, and always over $60 \%$ for any one transect. Evidence indicated that baits were taken by feral cats and foxes, and undoubtedly some were taken by other species as well. If oral bait is used in urban areas, nontarget species, specifically domestic animals, may ingest baits unless species-specific baiting techniques can be developed.

Baits were consumed by raccoons of all age and sex classes. However, subadult and adult males accepted baits less frequently than other classes, with <one-half of these individuals being clearly marked. Although the movements and home range utilization of raccoons vary greatly between different habitats, as well as at different times of the year within the same areas, males tend overall to be more mobile than females (Kaufmann, 1983). Adult female movements are also restricted when they are weaning young (Anderson and Willis, 1982), as were most adult females in this study. The subadult females, who as a class had the highest bait acceptance, were also the age-sex class with the smallest home ranges and most conservative movement patterns (Manski, unpubl. data). Thus, one possible explanation for the lower rate at which males were marked may be that they were ranging over a wider area than were females and their young, and had a reduced chance of encountering baits, given the relatively limited area over which the baits were distributed.

Our findings also suggest that the number of marked young-of-yr could have been enhanced by a second bait drop later in the summer. Based on the number of adult females caught and estimates of average litter size in Maryland (Dunn and Chapman, 1983) and North Carolina (Zeveloff and Doerr, 1981) we expected approximately 30 young in the study area. Seventeen were caught in July, of which 11 (64\%) were marked. Nine were caught in October, with no evidence that any of them had been marked. This second group of young was probably not weaned and travelling with their mothers at the time baits were distributed.

It has not been determined what percentage of a raccoon population must be vaccinated to significantly reduce an urban raccoon rabies epizootic, but this study indicates that at least $63 \%$ of a population can be reached by baiting. The immigration of unmarked and emigration of marked animals undoubtedly reduced the percentage of marked animals in our sample. Also, the edge effect is greater in small 
study areas such as ours. Further studies in larger areas may indicate that the method can approach the $70 \%$ vaccination rate commonly accepted as effective in limiting disease transmission in most control programs.

Although IA has been demonstrated to be an effective seromarker in raccoons (Larson et al., 1981; Baer et al., 1985), it is not possible to estimate how many baits an animal may have eaten simply on the basis of its blood iodine level. The findings indicate, however, that considerable individual variability in bait acceptance or exposure occurred within the study population, with some individuals not being marked, some being marked lightly and others being heavily marked. This, together with the finding of variability in acceptance between age-sex classes, indicates that further work is needed to delineate the factors underlying raccoon acceptance of baits.

The present study demonstrates that baits distributed in an urban park area will be accepted by raccoons; it leaves undetermined the many logistical and other factors to be considered for reaching raccoons living in residential and commercial areas. Other immunization strategies, such as trap-vaccinate-release (TVR) programs, may be more feasible and effective in areas where private property ownership predominates. A successful test of TVR has been applied to skunks and raccoons in metropolitan Toronto, Canada (Rosatte et al., 1987). A combined program, of oral baiting and TVR (where oral baiting is not feasible), could be an effective method for rabies immunization of urban raccoon populations. The use of strategically located feeding stations, where baits would be available, also should be investigated, since raccoons are known to be attracted to centralized feeding sites (Sharp and Sharp, 1956; Slate, 1985).

Many details of oral bait acceptance in urban raccoons remain to be determined, not the least of which are the development and production of an effective and safe oral vaccine. The technique shows great promise as an effective and cost-efficient method of reaching urban raccoons. The potential application of this method is considerable, and the procedure holds promise for those interested in facing the complex problems of urban wildlife population management and disease control.

\section{ACKNOWLEDGMENTS}

We thank the Superintendent of Rock Creek Park, Georgia Ellard, for permission to work there and for support during all phases of the study. The Natural Resources Manager for Rock Creek Park, Bob Ford, and his staff provided assistance and support in innumerable ways. William Anderson and Richard Hammerschlag provided valuable insights and commentary throughout the project. A number of volunteers assisted in bait preparation and distribution and are thanked for their contributions. Use of trade names is for identification only and does not imply endorsement by the National Park Service or the United States Department of the Interior.

\section{LITERATURE CITED}

ANDERSON, S., AND G. W. WILLIS. 1982. The raccoon (Procyon lotor) on St. Catherines Island, Georgia. 8. Reduction in summer home ranges by females. American Museum Novitates 2751: 1-5.

Baer, G. M., M. K. Abelseth, and J. G. Debbie. 1971. Oral vaccination of foxes against rabies. American Journal of Epidemiology 93: 487-490. , J. H. Shaddock, J. H. Hayes, and P. SaVARIE. 1985. Iophenoxic acid as a serum marker in carnivores. The Journal of Wildlife Management 49: 49-51.

Bigler, W. J., AND G. L. HoFf. 1974. Anesthesia of raccoons with ketamine hydrochloride. The Journal of Wildlife Management 38: 364-366.

Dunn, J. P., and J. A. Chapman. 1983. Reproduction, physiological responses, age structure, and food habits of raccoon in Maryland, USA. Zeitschrift für Saugetierkunde 48: 161-175.

HoffmanN, C. O., and J. L. Gottschang. 1977. Numbers, distribution and movements of a raccoon population in a suburban residential community. Journal of Mammalogy 58: 623-636.

JENKins, S. R., AND W. G. WinkLer. 1987. Descriptive epidemiology from an epizootic of raccoon rabies in the middle Atlantic states, 19821983. American Journal of Epidemiology 123: 429-437.

Johnston, D. H., D. R. Voigt, C. D. Macinnes, P. Bachmann, K. F. Lawson, and C. E. Rup- 
PRECHT. 1989. An aerial baiting system for attenuated or recombinant rabies vaccine for foxes, raccoons and skunks. Reviews of Infectious Diseases 10 (Supplement): In press.

KaufmanN, J. H. 1983. Raccoon and allies. In Wild mammals of North America, J. A. Chapman and G. A. Feldhamer (eds.). The Johns Hopkins University Press, Baltimore, Maryland, pp. 567-585.

Knowlton, F. F., P. J. Savarie, C. E. Wahlgren, AND D. J. HAYES. 1987. Retention of physiological marks by coyotes ingesting baits containing iophenoxic acid, mirex, and rhodamine B. In Vertebrate pest control and management materials, Vol. 5, ASTM STP 974, S. A. Shumake and R. W. Bullard (eds.). American Society for Testing Materials, Philadelphia, Pennsylvania, pp. 141-147.

Larson, G. E., P. J. Savarie, and I. Okuno. 1981. Iophenoxic acid and mirex for marking wild, bait-consuming animals. The Journal of Wildlife Management 45: 1073-1077.

Lawson, K. F., J. G. Black, K. M. Charlton, D. H. Johnston, AND A. J. Rhodes. 1987. Safety and immunogenicity of a vaccine bait containing ERA strain of attenuated rabies virus. Canadian Journal of Veterinary Research 51: 460-464.

LEWIS, N., AND F. W. Clark. 1973. Correction for sprung traps in catch/effort calculations of trapping results. Journal of Mammalogy 54: 295-298.

MANSKI, D., AND J. HADIDIAN. 1987. Raccoon ecology in and adjacent to an urban national park. In Integrating man and nature in the metropolitan environment, L. W. Adams and D. L. Leedy (eds.). National Institute for Urban Wildlife, Columbia, Maryland, p. 237.

Montgomery, G. C. 1964 . Tooth eruption in preweaned raccoons. The Journal of Wildlife Management 28: 582-584.

RosatTe, R. C. 1985. The study of rabies in urban wildlife. Environmental Health Review 29: 5-6.

, P. M. Kelly-Ward, and C. D. Macinnes 1987. A strategy for controlling rabies in urban skunks and raccoons. In Integrating man and nature in the metropolitan environment, L. W. Adams and D. L. Leedy (eds.). National Institute for Urban Wildlife, Columbia, Maryland, pp. 162-167.
ROSNER, B. 1986. Fundamentals of biostatistics. Duxbury Press, Boston, Massachusetts, 584 pp.

SANDERSON, G. C. 1950 . Methods of measuring productivity in raccoons. The Journal of Wildlife Management 14: 389-402.

- 1961. Techniques for determining age of raccoons. Illinois Natural Historical Survey Biological Notes 45: 1-16.

Schinner, J. R., and D. L. Cauley. 1974. The ecology of urban raccoons in Cincinnati, Ohio. In A symposium on wildlife in an urbanizing environment, J. H. Noyes and D. R. Progulske (eds.). University of Massachusetts, Springfield, Massachusetts, pp. 125-130.

SCHNEIDER, L. G., G. WACHENDORFER, E. SCHMITTDIEL, AND J. H. COX. 1983. Ein Feldversuch zur Oralen Immunisierung von Fuchsen gegen Tollwut in der Bundesrepublik Deutschland. II. Plannung, Durchfurung und Auswertungdes Feldversuch. Tierartzliche Umschau 38: 476-480.

Sharp, W. M., AND L. H. Sharp. 1956. Nocturnal movements and behavior of wild raccoons at a winter feeding station. Journal of Mammalogy 37: 170-177.

SLATE, D. 1985. Movement, activity and home range patterns among members of a high density suburban raccoon population. Ph.D. Dissertation. Rutgers University, Brunswick, New Jersey, 112 pp.

Steck, F., A. Wandeler, P. Bichsel, S. Capt, AND L. SCHNEIDER. 1982. Oral immunization of foxes against rabies. Zentralblatt für Veterinaermedizin Reihe B 29: 372-396.

STUEWER, F. W. 1943. Raccoons: Their habits and management in Michigan. Ecological Monographs 13: 203-257.

WinkleR, W. G., AND G. M. BAER. 1976. Rabies immunization of red foxes (Vulpes fulva) with vaccine in sausage baits. American Journal of Epidemiology 103: 408-415.

Zeveloff, S. I., AND P. D. Doerr. 1981. Reproduction of raccoons in North Carolina. Journal of the Elisha Mitchell Scientific Society 97: 194199.

Received for publication 24 February 1988. 